International Journal of Social Sciences and Humanities
Available online at http://sciencescholar.us/journal/index.php/ijssh
Vol. 3 No. 3, December 2019, pages: 36 49
e-ISSN: 2550-7001, p-ISSN: 2550-701X
https://doi.org/10.29332/ijssh.v3n3.354

\title{
Formative Assessment as Tool to Improve on Teaching Process-Learning for Students
}

\author{
CrossMark
Betty Alexandra Paredes Palacios a , Rosa Elena Posligua Anchundia ${ }^{\text {b }}$, Carlos Alfredo Robles Pihuave ${ }^{c}$, Jinsop Omar Bermello Vidal ${ }^{\mathrm{d}}$

Article history: Received 18 April 2019, Accepted: 31 August 2019, Published: 03 November 2019

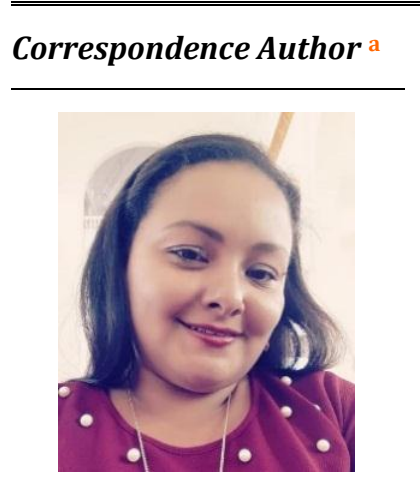

Keywords

decision-making; evaluative practices; teaching-learning; training assessment; training processes;

\begin{abstract}
In the Educational Unit, June 5 Garden of the city of Manta, research related to formative evaluation was carried out, to measure the learning-teaching process, the goal is to determine how the processes behave in the students. Analysis and synthesis methods were used to obtain the results that were processed and analyzed, and reference of scientific documents was consulted. The results of the surveys provide relevant information where, it is evident that teachers prefer to continue applying the old educational tools in the teaching-learning process, highlighting the results of the assessments to improve learning teaching training processes.
\end{abstract}

e-ISSN: 2550-7001, p-ISSN: 2550-701X ๑ Copyright 2019. The Author. SS Journals Published by Universidad Técnica de Manabí. This is an open-access article under the CC BY-SA 4.0 license (https://creativecommons.org/licenses/by-sa/4.0/) All rights reserved.

\section{Contents}

Abstract

1. Introduction

2. Materials and Methods

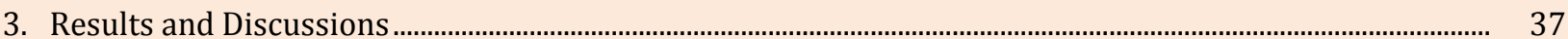

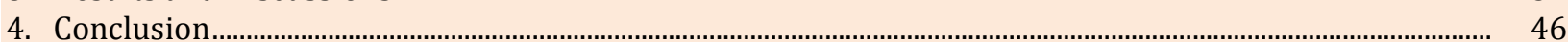



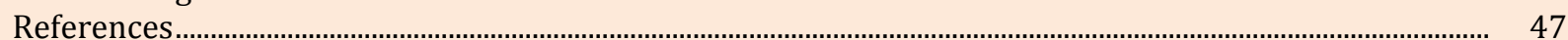

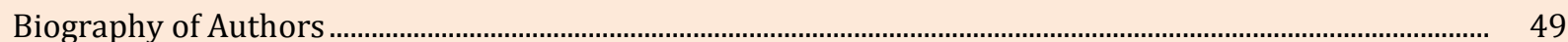

a Pontificia Universidad Católica del Ecuador sede Manabí, Manta, Ecuador

b Pontificia Universidad Católica del Ecuador sede Manabí, Manta, Ecuador

c Pontificia Universidad Católica del Ecuador sede Manabí, Manta, Ecuador

d Universidad Laica Eloy Alfaro de Manabí, Manta, Ecuador 


\section{Introduction}

Every evaluation emphasizes the pace of knowledge, this research allows us to know the formative assessment as a tool to improve the teaching-learning process in students, a study that has been conducted in the Unidad Educativa 5 de Junio del cantón Manta.

With regard to exordium, it is necessary to emphasize that at the Universidad de Velladolld, Chile, a study was conducted on the effects of the use of formative evaluation processes on students of physical pedagogy, where they showed how relevant the training assessments for learning orientation, as it deepens knowledge by incorporating standardized processes focused on student learning (Gallardo, 2018).

The formative assessment guides the knowledge that a student is acquiring, so it is a league or the competition assessment to be effective and regulatory, able to get the student himself self-assessing by acquiring a knowledge of quality, these activities can be innovative.

At the Technical University of Babahoyo, Ecuador, research was carried out on the formative assessment of the impact on the teaching and learning process, where the timely evaluation is evident as an indispensable tool for the training of students, the same that must be applied under techniques, dynamic activities, to obtain effective action within the classroom, action that must be fulfilled by all teachers as a powerful weapon in the learning process (Ramos, 2016).

The training assessments allow measuring the teaching and learning process by showing the knowledge of the people, in order to carry out competitive strategies, to improve the capacity to acquire learning.

As for the research carried out by the Laica Eloy Alfaro University of Manabí, Ecuador with the theme evaluation system to promote meaningful learning as a case study, it was found that the purpose for meaningful learning, should be under the formative assessment process to contribute to student training by building a pedagogy that transforms prior knowledge to long-term knowledge, taking into account the information cultivated as a fruit improve society (Estrada \& Zambrano, 2016).

This work is of an investigative -analytical nature, researched the formative evaluation and its application as a tool to improve the teaching process - learning in students, Unidad Educativa 5 de Junio- Jardín de la ciudad de Manta.

It is important to know how the different types of evaluation are currently applied in educational institutions, in order to establish the interest of the teachers who have the evaluation and how to apply it, in order to obtain better results in the encourage the development of learning skills. It was considered to be of paramount importance to apply formative assessment as its use improves teaching work and improves the teaching processes that are developed in academic institutions.

\section{Materials and Methods}

This research was carried out in the Unidad Educativa 5 de Junio - Jardín de la ciudad de Manta of the sectoral Revancha, exploratory research was applied, using the method of analysis and synthesis, enabling the interpretation of the found data, surveys were applied to teachers to obtain information on the use of formative assessment, in the process of teaching-learning. The results were processed and analyzed, based on the scientific documents consulted.

\section{Results and Discussions}

Today the evaluation has become one of the most relevant topics, not only in the educational field but also in the field of work and social, since there are many aspects in which people's knowledge is evaluated. Some educational research showed that the evaluation systems used by teachers are decisive in the way students learn, study and have a great influence on the content being taught and how they are taught (Alvarez, 2001).

Palacios, BAP, Anchundia, REP, Pihuave, CAR, \& Vidal, JOB (2019). Formative assessment as tool to improve on teaching process - learning for students. International Journal of Social Sciences and Humanities, 3 (3), 36-49. 
As the study of the evaluation points out, it is to create a teaching environment that integrates both learning and evaluation, inside and outside the class, taking into account the contextual factors (social, psychological and pedagogical) that influence the development of Learning (Kember \& Leung, 2007).

\section{Teaching-learning process}

Teaching-learning processes are a phenomenon that lives and creates an intentional communication system, which occurs in the student in an institutional framework generating strategies aimed at improving learning (Meneses, 2007).

The teaching-learning process distinguishes four essential elements that make up it: the teacher, the student, the content and environmental variables that are the characteristics of the school or the classroom, which have an influence on greater or lesser depending on the form that is related in a given context (Torres \& Girón, 2009).

By analyzing each of these four elements shown in Figure 1, the main variables of influence of the teachinglearning process are identified:



Figure 1. Elements of the teaching-learning process

Source: (Torres \& Girón, 2009).

The assessment

The evaluation can be conceptualized as a dynamic, continuous and systematic process, focused on changes in behaviors and returns, through which the achievements acquired are verified according to the proposed objectives (Figueroa, 2007; Macías et al., 2018).

The current education system and teacher training essentially take students' academic or school processes by generating specific tasks that are evaluated to understand the progress of students, through formative assessment. 
The evaluation consists of a systematic and rigorous data collection process, incorporated into the educational process from the beginning. In this way it is possible to have continuous and meaningful information to know the situation, form value judgments regarding it and make the right decisions to continue the educational activity by progressively improving it (Casanova, 1995).

The formative evaluation assumes a systematic process that allows the teacher to observe the progress of the educating, is associated with the summative and diagnostic evaluation. The intervention of this evaluation manages in an integral and holistic way to evaluate the learning process inside and outside the classroom with the students, contemplating obtaining the information necessary for the process guiding and motivating the descent.

On the other hand, it is assumed that evaluation is an instrument of dialogue, understanding, and improvement of educational practice (Santos, 1993). Currently, many authors talk about evaluation as a collaborative reality, must participate in the whole evaluation process: collecting data, analyzing it, making decisions and subsequently improving proposals.

The evaluation becomes meaningful as it checks the effectiveness and allows the improvement of the teacher's action, is understood as a source of improvement, continuously evaluating is how it is achieved to improve progressively, it allows to know what happens in the value and act more effectively (Duarte, 2003; Alava \& Martinez, 2019).

\section{Features of the Assessment}

The formal evaluation has as its characteristic to know the achievements of the students, in the process of teaching and learning. In addition, students' intermediate behavior can be assessed, promoting the necessary adjustments for the development of knowledge, skills, and skills.

The formative evaluation is facilitated during the term of a topic or content, is quantitatively and individually, which collects information about the results in order to adjust the acquired knowledge. Figure 2, shows the characteristics of the formative evaluation, where the factors necessary for the learning process are evidenced.

Palacios, BAP, Anchundia, REP, Pihuave, CAR, \& Vidal, JOB (2019). Formative assessment as tool to improve on teaching process - learning for students. International Journal of Social Sciences and Humanities, 3 (3), 36-49. 


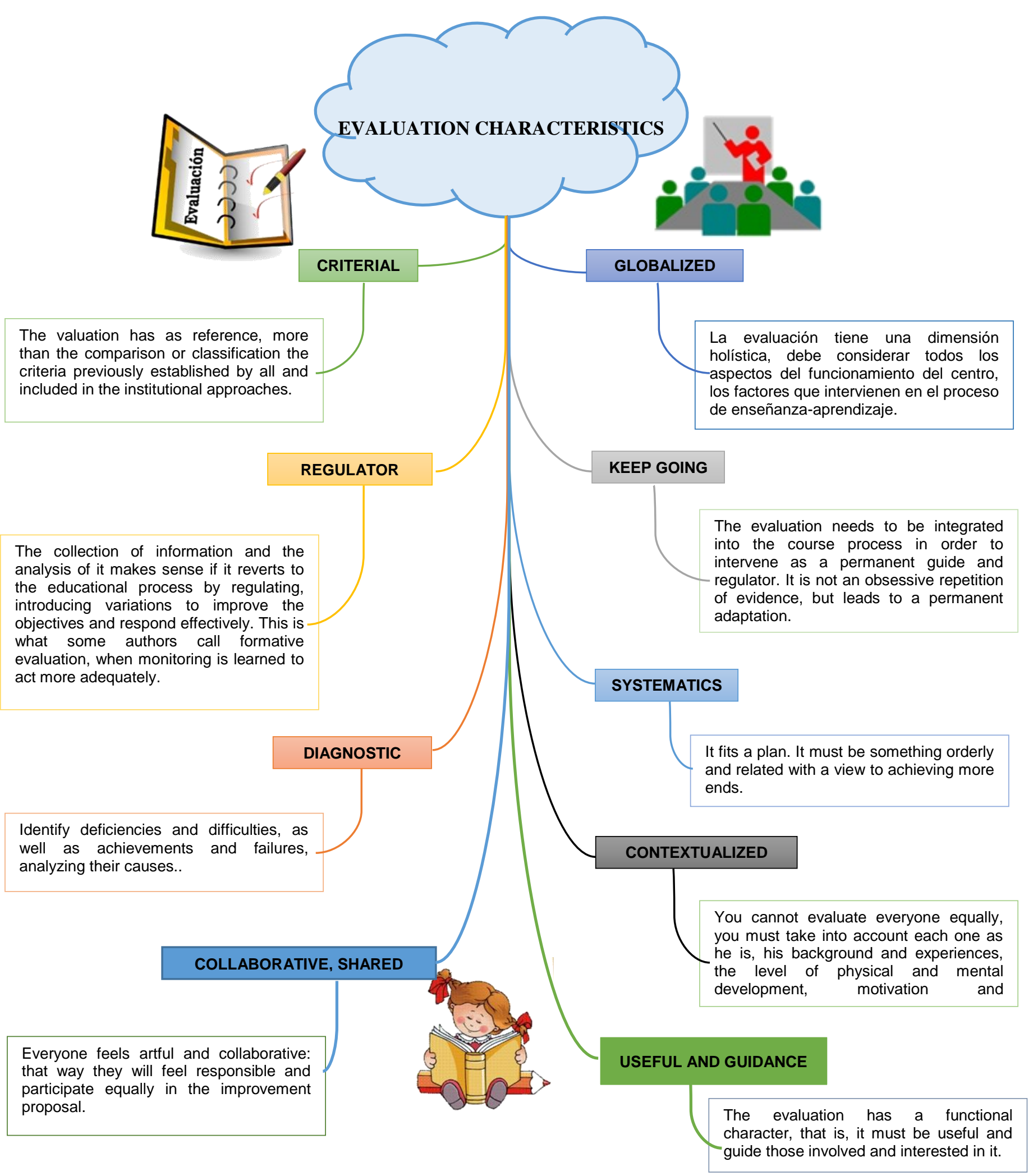

Figura 2. Características de la evaluación educativa Source: (García \& Pérez, 1989). 
Purpose of the evaluation

The training function of the evaluation aims to observe, accompany and analyze the processes and results of the students, identify strengths and difficulties, determine based on the reinforcement actions applied by the teachers. It is essential that the student on that route feels supported, satisfied, motivated and willing to do things differently if necessary (Fernández et al., 2018).

For a long time, teachers paid exclusive attention to the evaluation of results at the end of a learning unit or the school year, with the purpose of assigning a grade. The attention deserves the development of the learning process and evaluation was not paid. Thus, the possibilities of correcting errors in a timely manner, seeking background to find alternative pedagogical strategies, addressing individual differences, adjusting times were wasted. Feedback the teaching-learning process is essential for students to achieve the expected learnings, considering their different rhythms, so the need to recover the process assessment in pedagogical practice has been pointed out (Cabrerizo \& Castillo, 2003).

The teaching-learning process becomes important as it effectively leads to the expected learning and the achievement of the objectives demanded by the Curriculum Framework, represents the professional commitment that the teacher has acquired with his Students. The results of the process are very important, as well as the summative evaluation, these reports on the quality of the learnings achieved at the end of the teaching cycle. The evaluation cannot be prevented from continuing to fulfill a structural function of certification. The evaluation of the final results of learning with summative intent is essential. As mentioned above, both procedures are not exclusive, but necessarily complementary.

In short, in terms of the functions of the evaluation within the teaching-learning process, the diagnostic, formative and summative evaluation work together, the desired balance is achieved and the evaluation can be the tool that the teacher needs to conduct their teaching effectively. Everything in education has been found to be relatively evaluable, which does not mean that it is numerically evaluable or quantifiable.

As Professor Ken Bain points out, external rewards are proven to produce ephemeral effects and loss of interest. The author states that, if it is customary for students to be interested only in the note, lasting learning is not contributed and strategic apprentices would be encouraged, such as those students who develop skills to obtain good but avoid the challenges and development of a deeper understanding; they fear to make mistakes and rule out looking for other solutions, which reduces creativity (Bain, 2007).

\section{Classification of the assessment}

The evaluation can be classified in different ways, depending on the optics we want to take, for example:

According to the extension as: overall evaluation and partial evaluation; according to the evaluation agents such as: internal evaluation, self-assessment, hetero evaluation, co-evaluation, and external evaluation; depending on the time of application such as: initial evaluation, course evaluation and final evaluation; but the classification that we are currently interested in is according to its purpose and function, therefore, it is divided into two.

Training function: the evaluation is preferably used as an improvement strategy, to adjust on the fly, the educational processes to achieve the expected goals or objectives. It is the most appropriate for the evaluation of processes, although the evaluation of educational products is also formative, provided that their results are used to improve them. It is usually identified with continuous evaluation (Onetti, 2011).

Summative function: it is usually applied more in the evaluation of products, finishing processes, with precise and valuable realizations. With the evaluation it is not intended to modify, adjust or improve the purpose of the evaluation, simply to determine its worth, depending on the use that is desired to make it (Onetti, 2011).

\section{Formative Assessment}

The formative evaluation is considered one of the most important in any learning process, it is the one that allows maintaining a permanent and continuous monitoring of the learning of students, their difficulties and

Palacios, BAP, Anchundia, REP, Pihuave, CAR, \& Vidal, JOB (2019). Formative assessment as tool to improve on teaching process - learning for students. International Journal of Social Sciences and Humanities, 3 (3), $36-49$.

https://doi.org/10.29332/ijssh.v3n3.354 
advances, to intervene in time and perform the changes, improvements, and adjustments that are necessary, both in our methodologies and in the planned activities and evaluations. The goal is not to get a grade.

Himmel indica, para que la evaluación sea realmente formativa, la retroinformación debe proporcionar evidencia útil al aprendiz, describa claramente las fortalezas y debilidades de desempeño, requiere ser suministrada en forma oportuna y frecuente, de modo que pueda percibir oportunamente los efectos de su esfuerzo y su progreso en el aprendizaje (Himmel, 2003).

The author expresses that, through the formative evaluation, the student acquires and endorses the criteria and standards necessary to carry out the self-assessment of performance and achieve autonomy to direct it.

It can be said that the formative evaluation does the semaphore. She indicates whether the student, curriculum and teacher are aligned in the review of the teaching-learning process. It helps to achieve better results in students, such as promoting the development of lifelong learning skills, perfecting the teaching task and improving the teaching processes that develop in educational institutions.

Formative assessment is very useful both for students in improving learning, and for the teacher as an education professional.

\section{Contributions from the Formative Assessment}

Professor Dr. Ramón Pérez Juste proposed three key contributions of formative evaluation: information for guidance and decision-making, improvement of the program and data for professional improvement (Perez, 1989).

American educator Benjamin Bloom in relation to training tests states:

It is believed that training tests should not be accompanied by quality ratings or scores. The tests are prepared to show the domain or lack of the domain and the assessment of the lack of the domain is accompanied by a detailed diagnosis and a prescription of what has yet to be done before the domain has been completed (Bloom, 1956).

Under this criterion, the teacher contributes to the success of the student through the study program, following the fulfillment of the objectives developed in the contents, using the means that are available for the student's learning, if it does not take responsibility for the curriculum, its success is not assured despite the teacher's work. Programs will always achieve partial levels of success and also a failure. This is when the formative evaluation comes in to play the role, through it you can identify the strengths and weaknesses, present the necessary modifications to consolidate them and control the causes that gave rise to it. It should be considered that no matter how careful it is in the preparation of the program, it will not always respond fully to the desired quality, because this is a matter of continuous improvement.

\section{The main function of formative assessment}

The main function of the evaluation is to be a guide. Although several educators overlook it and focus on the quantitative aspect of the grade, the role is to evaluate the student's learnings and do so using the results of the information collected to guide the student in achieving the goals of learning, that's where formative assessment comes in as part of the guiding role of evaluation.

The guiding function helps to develop projects and programs on basic aspects that the student must achieve. This function is closely linked to the time of initial evaluation and the effects that are extracted from it: diagnosis and prognosis. Within the formative evaluation has numerous advantages such as the following: measurement of what it does, professional formative validity and values, habits and skills; measurement of multiple attributes; measure performance over time; multiplicity of observers; constructive feedback; availability of scenarios and information to students about their training (Hamodi \& Tejada, 2011).

These authors also manage a number of limitations in the development of formative evaluation that relies more on subjective issues such as the lack of standardization since there is no scheme for their development, the little implementation, this is essential in well-trained evaluators to avoid improvisation, and nonfulfillment of the objectives set, when assessing the performance of students. By performing a correlation, it can be seen that the advantages are higher, the limitations can be solved with the educational and systemic work of the teachers. 
Advantages of formative assessment, allow to make the diagnosis of weaknesses in students, favors dialogue between the teacher and them, stimulates self-assessment, helps to develop skills for independent study, informs the student of their deficiencies, measures the progress made and its trend in the educational process. The formative evaluation can never be used to make a certified judgment, with which other works consulted and the authors of this review coincide (Victor, 2011).

\section{Evaluation instruments}

The formative assessment should provide the teacher with sufficient evidence of judgment so that he can make decisions with precision and assurance, in the development of knowledge. For this you must know the learning possibilities of each of your students, how they are learning, their pace, their difficulties, must access reports that can be interpreted, fed-up and motivate, reinforce or provide help.

It is very important to distinguish between teaching resources and evaluation tools. While the former makes it easier for the student to learn their learning process, the tools are used by Professor All assessment tools are teaching resources, but not all teaching resources are evaluation tools.

These tools serve teachers to collect the necessary information in the evaluation process (Castejón et al., 2011). The classification of evaluation instruments according to their oral, written or observational statement is presented in Table 1. So, some examples of each of them.

Table 1

Evaluation instruments

\begin{tabular}{ll}
\hline $\begin{array}{l}\text { Classification in relation to its } \\
\text { function }\end{array}$ & Examples \\
\hline $\begin{array}{l}\text { Instruments with the predominance } \\
\text { of written expression. }\end{array}$ & $\begin{array}{l}\text { Exam, written work, essay, poster, report, project, field notebook, } \\
\text { practical sheets, diary, folder or dossier, portfolio, and memory. }\end{array}$ \\
$\begin{array}{l}\text { Instruments with a predominance of } \\
\text { oral expression }\end{array}$ & $\begin{array}{l}\text { Exhibition, debate, interview, group interview, discussion group, } \\
\text { round table, a panel of experts, presentation and communication }\end{array}$ \\
\hline
\end{tabular}

Source: (Castejón et al., 2011)

Cycle of formative assessment

The evaluation always contemplates the cycle: obtaining information, formulating value judgments and making decisions, in the case of formative evaluation should be indicative, regulatory and motivating. Royce Sadler believes that feedback is information that refers to a student's success in the execution or performance of an academic task (Sadler, 1989).

The formative evaluation cycle is based on the completion of three basic questions as shown in Table 2 .

Table 2

Questions from the formative assessment cycle

\begin{tabular}{|c|c|c|}
\hline Where are we going? & Where are we going? & Where are we? \\
\hline $\begin{array}{l}\text { The formative evaluation begins from } \\
\text { the moment the teacher shares what } \\
\text { the learning goals are and the results } \\
\text { to be achieved, subsequently, the } \\
\text { criteria of achievement are clarified. }\end{array}$ & $\begin{array}{l}\text { At this stage, the first thing to } \\
\text { do is to collect evidence } \\
\text { through evaluations, followed } \\
\text { by interpreting the results and } \\
\text { identifying the learning gap. }\end{array}$ & $\begin{array}{l}\text { This stage of the cycle is } \\
\text { closely related to feedback. }\end{array}$ \\
\hline
\end{tabular}

Source: (Sadler, 1989)

This last part requires feedback to students by offering them criteria about their teaching-adjusted performance and finally being able to close the gap.

Palacios, BAP, Anchundia, REP, Pihuave, CAR, \& Vidal, JOB (2019). Formative assessment as tool to improve on teaching process - learning for students. International Journal of Social Sciences and Humanities, 3 (3), 36-49. https://doi.org/10.29332/ijssh.v3n3.354 
Survey result

The information obtained through the surveys applied to the teachers of the Educational Unit "June 5" was processed and analyzed by statistical figures to make possible the evidence of the determining factors found in that institution. The results of the research are set out below.

Figure 3 shows the percentages that teachers indicated, 33\% use the summative assessment to assess pedagogical activities, 25\% through formative assessment, and $17 \%$ use self-assessment and hetero assessment to evaluate their school activities. Therefore, it can be noted that teachers expect to finish a cycle to evaluate knowledge in their students.



Figure 3. Types of evaluation

In the results obtained, teachers indicated by $50 \%$ that they use semi-formal assessments and the same percentage of formal assessments, determining that they take into account group or individual work, assignments, among other activities performed by students like exams and getting grades that allow them to measure students' results.

Figure 4 shows the results from the results teachers plan the activities, $98 \%$ responded that they plan the pedagogical activities, from the evaluations, while 8\% carry out it usually. It was said that they take into account the observations obtained to improve the learning-teaching process.

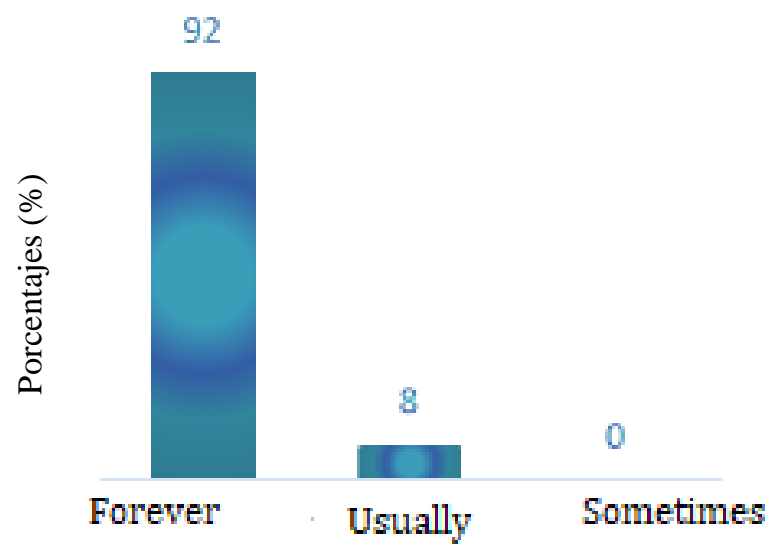

Figure 4. Planning activities based on evaluations

Figure 5 shows the results that teachers get when applying question banks, $67 \%$ indicated that it is necessary and to value students through this methodology, 33\% mentioned that they usually use them. Based on analysis related to the evaluation of students prioritizing written tests, regardless of the need for activities carried out within the learning teaching process to measure the final results. 


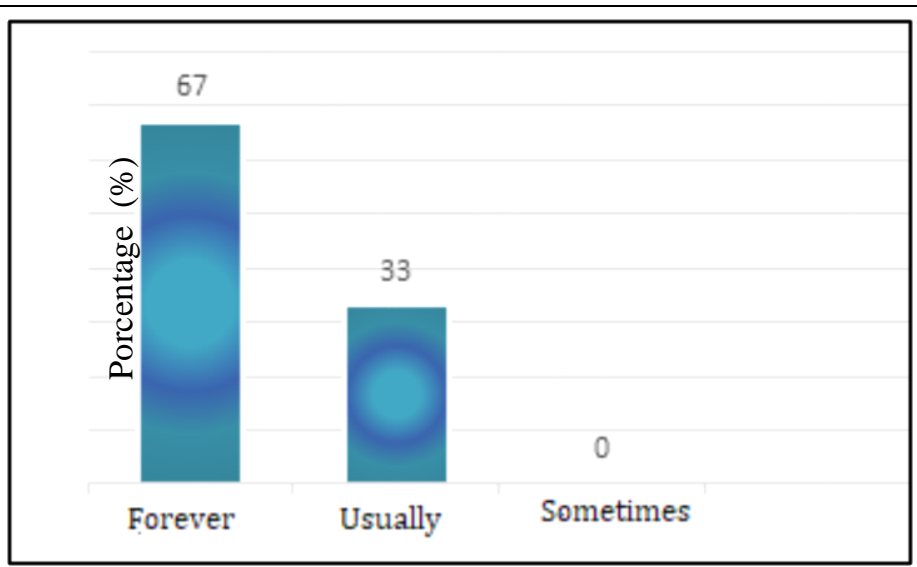

Figure 5. Application of question banks to evaluate

Figure 6 shows the changes teachers make from the results they get in the evaluation, 58\% indicate that they perform group pedagogical reinforcements to improve learning $17 \%$ ealize personalized tutorings, and the same percentage carry out projects with students and $8 \%$ send homework. It is determined that teachers take into account the results of assessments to improve the teaching process - student learning.

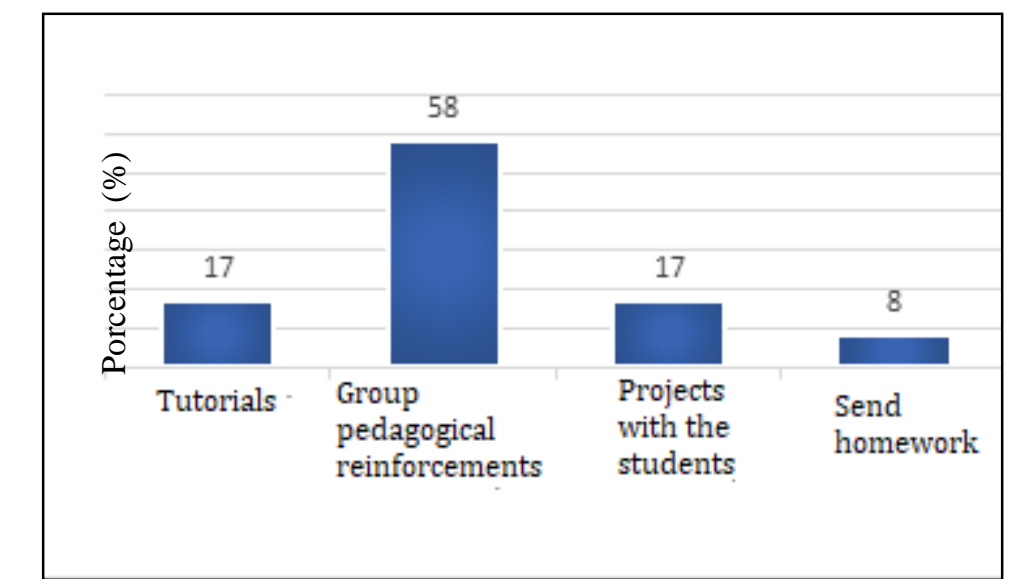

Figura 6. Cambios aplicados a partir de los resultados de la evaluación

With the data collected with the teachers, they mentioned that based on the results obtained in the evaluations they employ strategies of continuous improvement and the in a smaller percentage perform the evaluation to assess the knowledge of the students. It is important for teachers to generate alternatives that allow students to meaningfully assimilate knowledge and skills according to the level they are at the level they are.

In the Unidad Educativa 5 de Junio, the largest percentage of teachers use the summative assessment, prioritizing the use of question banks as means of evaluation, allowing, to verify results at the end of the entire educational cycle. A small group of teachers uses formative assessment, applying it through the entire learning process by valuing the activities students perform.

Most teachers indicate that from the evaluation results they plan the academic activities, using the necessary strategies to improve the learning-teaching process, looking for the necessary alternatives and thus get the students to acquire the knowledge according to the level they are in.

Palacios, BAP, Anchundia, REP, Pihuave, CAR, \& Vidal, JOB (2019). Formative assessment as tool to improve on teaching process - learning for students. International Journal of Social Sciences and Humanities, 3 (3), 36-49. https://doi.org/10.29332/ijssh.v3n3.354 


\section{Conclusion}

The reference authors agree that the Formative Assessment allows the teacher to maintain permanent and continuous monitoring of student learning, to intervene on time and make the necessary modifications, improvements, and adjustments. Surveys showed that $25 \%$ of the teaching staff of the Educational Unit June 5 - Garden actually applied the formative assessment. Teachers usually expect to complete a cycle to assess their students' knowledge, i.e. they do so not regularly but only because of the mandatory partial assessments. However, it is noted that most teachers do take action based on the results of these assessments, such as group tutoring.

At the same time, it was shown that most teachers use question banks at the time of evaluation and often exclude other tools that may be much more useful in determining the student's knowledge, this type of methods go against what formative assessment actually means and directly affects the teaching-learning process.

\section{Acknowledgments}

The authors would like to thank the reviewer for their consideration of the further process of the present paper. Thanks to the editor of IJSSH for the valuable support, time as well as advice. 


\section{References}

Alava, E. E., \& Martinez, M. E. M. (2019). Impact of teaching-learning process for brain. International Journal of Health Sciences, 3(1), 33-40. https://doi.org/10.29332/ijhs.v3n1.304

Bain, K. (2007). Lo que hacen los mejores profesores de universidad. Valencia: Servicio de Publicaciones Universidad de Valencia. Obtenido de https://www.fceia.unr.edu.ar/geii/maestria/2014/DraSanjurjo/8mas/Ken\%20Bain,\%20Lo\%20que\%20h acen\%20los\%20mejores\%20profesores\%20de\%20universidad.pdf

Bloom, B. S. (1956). Taxonomy of educational objectives. Vol. 1: Cognitive domain. New York: McKay, 20-24.

Cabrerizo, D., \& Castillo, S. (2003). Prácticas de Evaluación Educativa: Materiales e Instrumentos. Pearson Educación.

Casanova, M. A. (1995). Manual de evaluación educativa. España: La Muralla.

Castejón Oliva, FJ, López-Pastor, VM, Julián Clemente, JA, \& Zaragoza Casterad, J. (2011). Formative evaluation and academic performance in the initial training of physical education teachers formative assessment and academic performance in pre-service physical.

Duarte, D. (2003). Learning environments: a conceptual approach. Pedagogical studies (Valdivia), (29), 97 113. http://dx.doi.org/10.4067/S0718-07052003000100007

Fernández Noguel, M., Bauza Barreda, BM, \& Hechavarria Almaguer, E. (2018). Proposals of integrative and formative evaluation activities in the initial preparation of the geography teacher. Atlante Notebooks of Education and Development, (July).

Gallardo, F. (2018). Efectos de la utilización de procesos de evaluación formativa en los estudiantes de Pedagogía en Educación Física de la Universidad de los Lagos (Chile). Obtenido de (Tesis doctoral). Universidad de Vallodolld, Los Lagos, http://uvadoc.uva.es/bitstream/handle/10324/33110/Tesis1441181130.pdf;jsessionid=302E2284234BE1EA2E3FD25653818479? sequence $=1$

García, J., \& Pérez, R. (1989). Diagnóstico, evaluación y toma de decisiones. Madrid: Rialp Ediciones.

Hamodi, G., \& Tejada, J. (2011). La evaluación de las competencias en contextos no formales: dispositivos e instrumentos de evaluación. Rev de Educación. Obtenido de http://dide.minedu.gob.pe/handle/123456789/983

Himmel, E. (2003). Evaluation of learning in Higher Education: A necessary reflection. Educational Thought Magazine, 33, 199-211.

Kember , D., \& Leung, D. (2007). Caracterización de entornos de aprendizaje capaces de fomentar capacidades genéricas en la educación superior. Springer Link, 609. Obtenido de https://doi.org/10.1007/s11162-0069037-0

Macías, E. I. P., Cedeño, H. A. C., \& Chávez, G. M. R. (2018). Importance of Improving Resilience in TeachingLearning Process of Students with Disabilities. International Research Journal of Management, IT and Social Sciences, 5(2), 120-128.

Marcano, M. Á. F. (2007). La evaluación y sus potencialidades en el contexto educativo tomando en consideración el valor predictivo de la prueba de selección que se aplica en la carrera de Administración... Fermentum. Revista Venezolana de Sociología y Antropología, 17(49), 334-357.

Méndez, J. M. Á. (2001). Evaluar para conocer, examinar para excluir. Morata.

Meneses, G. (2007). The teaching-learning process: the didactic act. NTIC, interaction and learning in the university. Spain: Rovira I Virgili University.

Molina, OE, \& Acosta, JMZ (2016). Assessment system to promote meaningful learning: case study. REFCalE: Electronic Magazine Training and Educational Quality. ISSN 1390-9010, 4 (1), 29-40.

Onetti, V. (2011). La Evaluación. Innovacion y Experiencia Educativas(39). Obtenido de https://archivos.csif.es/archivos/andalucia/ensenanza/revistas/csicsif/revista/pdf/Numero_39/VANESS A_ONETTI_ONETTI_1.pdf

Perez, J. R. (1989). Diagnóstico, Evaluación y toma de Decisiones. Valencia: UNED.

Ramos Morales, CL (2016). Formative evaluation and its impact on the teaching process of English language learning in tenth year students basic education of the Alberto Maldonado Iturburo educational unit located in the city of Babahoyo, province of the rivers (Bachelor's thesis, Babahoyo: UTB, 2016).

Palacios, BAP, Anchundia, REP, Pihuave, CAR, \& Vidal, JOB (2019). Formative assessment as tool to improve on teaching process - learning for students. International Journal of Social Sciences and Humanities, 3 (3), 36-49. 
Sadler, D. R. (1989). Formative assessment and the design of instructional systems. Instructional science, 18(2), 119-144. https://doi.org/10.1007/BF00117714

Santos, G. M. (1993). Evaluación Educativa 1. 23-35. Obtenido de https://idus.us.es/xmlui/handle/11441/59547

Torres, H., \& Girón, D. (2009). General Teaching Pedagogical Collection Initial Training of Central American Teachers of Primary or Basic Education, 9.

Victor, L. (2011). Evaluación formativa y rendimiento académico en la formación inicial. Rev Int Med Cienc Act Fís Deporte [Internet]. 


\section{Biography of Authors}

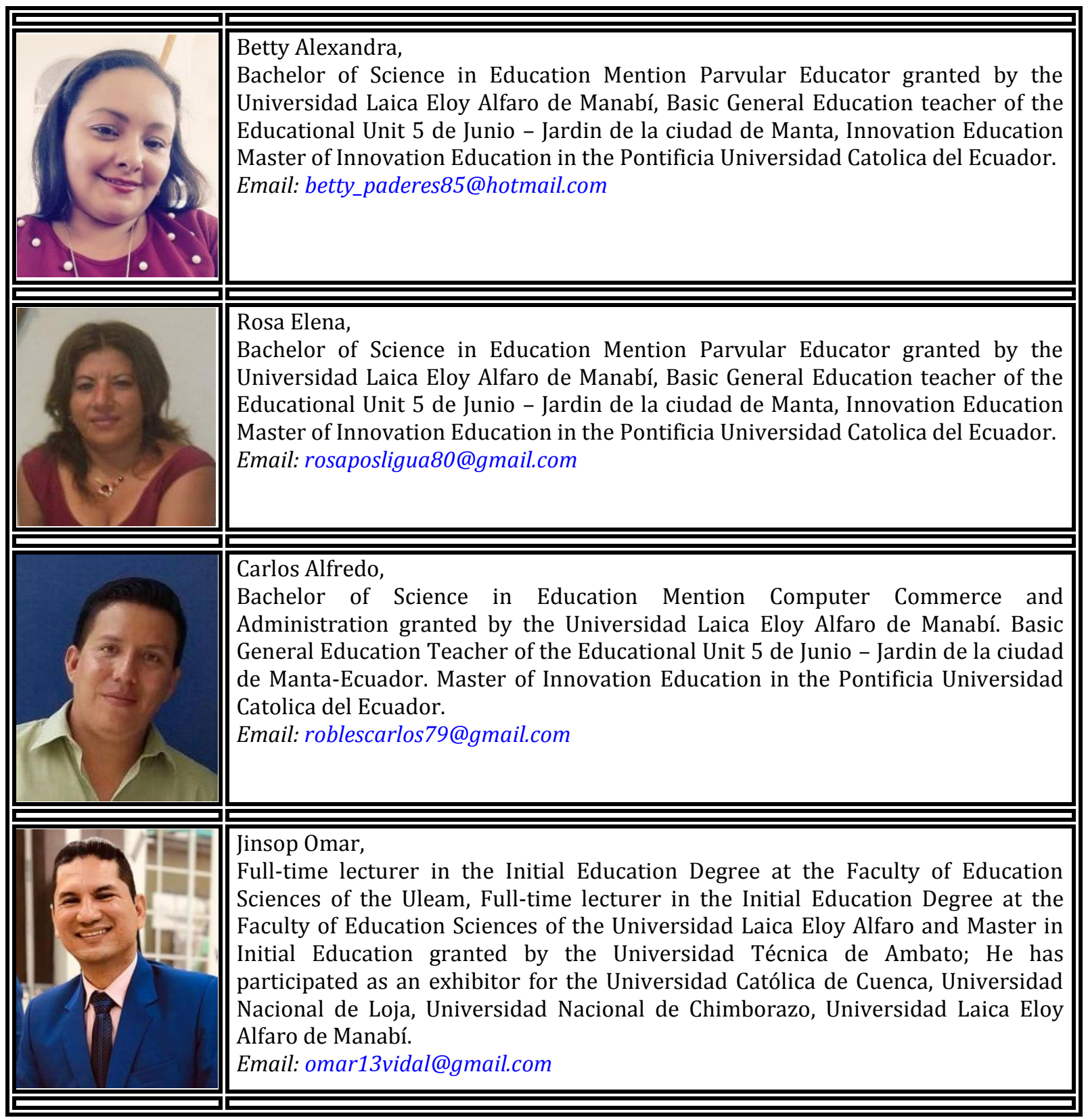

Palacios, BAP, Anchundia, REP, Pihuave, CAR, \& Vidal, JOB (2019). Formative assessment as tool to improve on teaching process - learning for students. International Journal of Social Sciences and Humanities, 3 (3), $36-49$. https://doi.org/10.29332/ijssh.v3n3.354 